\title{
Response to reduced dietary protein level on growth performance in growing Windsnyer pigs
}

\author{
Vuyisa A. Hlatini ${ }^{1} \cdot$ Michael Chimonyo $^{1}$ (1) $\cdot$ Cyprial Ndumiso Ncobela ${ }^{1,2} \cdot$ Ronald Sylvester Thomas $^{1,2}$
}

Received: 6 February 2020 / Accepted: 10 December 2020 /Published online: 23 January 2021

(C) The Author(s), under exclusive licence to Springer Nature B.V. part of Springer Nature 2021

\begin{abstract}
The objective of the study was to determine the growth performance response to reduced dietary protein level and to identify the optimum level of protein for the performance in growing Windsnyer pigs. Maize-soybean-based diets were formulated to contain a protein level of $193 \mathrm{~g} / \mathrm{kg}, 173.7 \mathrm{~g} / \mathrm{kg}, 154.4 \mathrm{~g} / \mathrm{kg}, 135.1 \mathrm{~g} / \mathrm{kg}, 115.8 \mathrm{~g} / \mathrm{kg}$ and $96.5 \mathrm{~g} / \mathrm{kg}$. The $193 \mathrm{~g} / \mathrm{kg}$ (control diet) is the standard recommended by the National Research Council. The amino acid levels and net energy value were similar in all treatments. The study was conducted with five growing Windsnyer pigs per each protein inclusion level. The trial was carried out with individually caged pigs aged 4 months, weighing about $23(\mathrm{SD}=1.39) \mathrm{kg}$. The experiment lasted a period of 8 weeks excluding 2 weeks of the adaptation period. The feed and water were offered ad libitum. The average daily feed intake (ADFI), average daily gain (ADG), feed conversion ratio (FCR), final body weight (FBW) and metabolic body weight $\left(\mathrm{BW}^{0.75}\right)$ were measured. Polynomial regression and piecewise regressions were used to analyse data. Decremental levels of protein did not affect $(p>0.05)$ ADFI and ADG. Reduced levels of protein influenced FBW, BW ${ }^{0.75}$ and FCR $(p<0.05)$. A decreasing quadratic response was observed in FCR, as CP decreased from $193 \mathrm{~g} / \mathrm{kg}$ to 135.1 , FCR improved from 3.18 to 2.13 then suddenly decreased with the $\mathrm{CP}$ level. There was a quadratic increase in $\mathrm{BW}^{0.75}$ and $\mathrm{FBW}$ as inclusion levels of protein were reduced $\left(p<0.05\right.$ ). They increased from $193 \mathrm{~g} / \mathrm{kg}$ (FBW 39.5 and BW $\mathrm{BW}^{0.75} 12.8$ ) protein level until $135.1 \mathrm{~g} / \mathrm{kg}$ (FBW 45.1 and $\mathrm{BW}^{0.75} 14.6$ ) then begun to decrease as dietary protein level was decreased further. Using stepwise piece (broken stick) methods, the optimum protein level for FCR was estimated to be at $135.1 \mathrm{~g} / \mathrm{kg}(p<0.05)$. The maximum level of dietary protein for BW and $\mathrm{BW}^{0.75}$ was obtained at $135.1 \mathrm{~g} / \mathrm{kg}$. Reduction of the CP level in the Windsnyer pig diet beyond $138.3,132.1$ and $132.3 \mathrm{~g} / \mathrm{kg}$ hinders the FCR, FBW and $\mathrm{BW}^{0.75}$, respectively. Protein levels can be reduced from the standard recommendation level of $193 \mathrm{~g} / \mathrm{kg}$ to $135.1 \mathrm{~g} / \mathrm{kg}$ without compromising the growth performance of growing Windsnyer pigs.
\end{abstract}

Keywords Feed conversion ratio $\cdot$ Feed intake $\cdot$ Indigenous pigs $\cdot$ Metabolic body weight, optimum protein level

\section{Introduction}

The commercial value of indigenous pigs to improve pig production has been gaining impetus (Nistor et al., 2012; Hlatini et al., 2020; Huang et al., 2020; Kasprzyk and Bogucka, 2020). This is due to the high demand for pork because of the ever-increasing human population coupled with climate

Michael Chimonyo

Chimonyo@ukzn.ac.za

1 Department of Animal and Poultry Science, University of KwaZulu-Natal, P bag X01 Scottsville, Pietermaritzburg 3209, South Africa

2 Present address: Agricultural Research Council-Animal Production Institute (Nutrition Building), Private Bag X 2, Irene 0062, South Africa change and pandemic diseases such as existing COVID-19. The demand for indigenous pork for fresh consumption is increasing. The demand for pork from indigenous pigs is also driven by the taste and preferences of the consumers. Thus, research that prioritizes indigenous pigs is relevant.

Indigenous pigs have the ability to produce under marginal nutrient availability. Indigenous pigs have also demonstrated the ability to utilize high fibrous diets due to their unique microbial community (Kanengoni et al., 2014; Ncobela et al., 2018). Indigenous pigs are commonly fed with energy-rich feedstuffs such as tree leaves, grasses, kitchen waste, maize cobs and local fruit, which are mostly enough for maintenance and low production. The low-quality protein in the diet fed to indigenous pigs could cause poor production performance. These energy-rich diets have either low protein levels or inadequate protein for utilization. 
Protein, which is an indispensable nutrient, supplies amino acids required for growth performance and production of pigs (Whittemore et al., 2001). An attempt to reduce protein content in the diet of pigs is a contemporary subject. The protein content is reduced to save the in-demand protein-rich ingredients and reduce feed cost for pigs (Wang et al., 2018). Reduction in the inclusion of protein in the diet of pigs reduces nitrogen in the excreta (Hlatini et al., 2020), which contributes to the emission of ammonia and nitrite gases (Hansen et al., 2014). High excreta nitrogen induces acidification and eutrophication of ecosystems and odour emissions (Mpendulo et al., 2018; Wang et al., 2018). Low-protein diets maintain gut health and positively influence intestinal morphology and microbiota (Wang et al., 2018).

There are several studies done aiming at reducing protein levels in the diet of fast-growing and slowgrowing pigs (Noblet et al., 2001; Heo et al., 2008; Gallo et al., 2014; Hansen et al., 2014; He et al., 2016; Wang et al., 2018). However, very few, if any, have attempted to precisely determine protein needs for indigenous pigs using piecewise regression. Inadequate supply of protein in the diet of pigs compromises protein synthesis and subsequently growth performance (Whittemore et al., 2001). On the other hand, supplying excess dietary protein fuels high protein turnover, muscle respiration and visceral organ mass (Noblet et al., 2001; Gallo et al., 2014; Toledo et al., 2014). Therefore, there is a need to accurately determine protein needs for indigenous Windsnyer without compromising growth performance.

Knowledge on the optimum protein requirements for indigenous pigs optimizes protein efficiency and guides feed formulators with protein requirements for Windsnyer pigs. The indigenous growing Moo Lath pigs required about $150 \mathrm{~g} / \mathrm{kg}$ of crude protein in the diet (Phengsavanh and Lindberg, 2013). The indigenous Mong Cai pigs showed a great performance on the diet with 130 to 140 dietary protein levels (Ly et al., 2003; Pham et al., 2010); similar findings were obtained in Cinta Senese pigs of Italy (Sirtori et al., 2010). Indigenous Windsnyer pigs might require less protein level than NRC (2012)-estimated protein intake for leaner and fast-growing pigs. The optimal protein level for indigenous Windsnyer pigs has not been defined. This necessitates research to determine the growth performance of the indigenous Windsnyer pigs given a diet that contains decreasing protein levels. The objective of the study was, therefore, to determine the response in the growth performance to reduced dietary levels in growing Windsnyer pigs. It was hypothesized that reduction of dietary protein level beyond optimum levels would compromise growth performance in indigenous Windsnyer pigs.

\section{Materials and methods}

\section{Study site description and ethical clearance}

The study was then conducted at the Agricultural Research Council (ARC), Animal Production Institute, Irene, South Africa. The average annual temperature during the period of the study was $20.7{ }^{\circ} \mathrm{C}$. The care and use of experimental animals were according to the approved standards by the Animal Ethics Committee of the Agricultural Research Council-Animal Production Institution (reference number APIEC 17/12).

\section{Pig management}

Thirty clinically healthy male slow-growing Windsnyer pigs of about 4 months of age, with an initial body weight of about $23(\mathrm{SD}=1.39) \mathrm{kg}$, were randomly allocated into individual pens measuring $1.5 \times 1 \mathrm{~m}^{2}$. The pigs were ear-tagged and housed in a barn with artificial lighting and a proper ventilation system. The house temperature and humidity were maintained at about $21.9 \pm 2.24{ }^{\circ} \mathrm{C}$ and $45.2 \pm 6.85 \%$, respectively. A 12-h dark-12-h artificial light cycle was applied. Each pen was provided with water through a low-pressure nipple drinker and feed was supplied in a self-feeder trough. Feed and water were offered ad libitum. The pigs received no antibiotics or growth promoters.

\section{Experimental diet and design}

The control diet contained $193 \mathrm{~g} / \mathrm{kg}$ protein level that was formulated according to the standards for the trial pig age recommended by NRC (2012). Then, the protein level was reduced at the expense of soybean meal to reach the desired low-protein diets containing 173.7, 154.4, 135.1, 115.8 and $96.5 \mathrm{~g} / \mathrm{kg}$ CP but with levels of essential amino acids the same as in the control. The six diets were formulated to have about 9.5 MJ in all diets. Low-protein diets were formulated by reducing the $\mathrm{CP}$ level through partial substitution of soybean meal by yellow maize and wheat bran. The experimental diets were formulated to meet and exceed NRC requirements for all other nutrients for growing pigs (NRC, 2012). Diets were formulated using the software program Bestmix ${ }^{\circledR}$ (Adifo, Belgium). Experimental diets were allocated randomly to pens and each pig was treated as an experimental unit, in a complete randomized design. There were five pigs for each dietary treatment. Before the commencement of data collection, pigs were allowed an adaptation period of 14 days to the environment and experimental diets. Then, Windsnyer pigs were fed experimental diets in mash form for 8 weeks. 


\section{Chemical analyses}

Representative diet samples were taken from all the feeders per dietary treatment 3 days after the beginning and 3 days before the end of the experiment. They were kept at a cool dry place until they were homogenized, subsampled and prepared for use for chemical composition analysis. All diet samples were analysed in triplicate (Table 1). Proximate analyses were determined using the Association of Official Analytical Chemists (AOAC, 1990). Dry matter, ash, crude protein and ether extract were analysed according to official methods, viz. 945.15, 942.05, 979.09 and 920.39, respectively. Nitrogen content was determined using the Dumas combustion method in a LECO TruSpec nitrogen analyser (St. Joseph, MI, USA). Crude protein was then calculated as $\mathrm{N} \times 6.25$. Neutral detergent fibre (NDF) and acid detergent fibre (ADF) levels were analysed using a ANKOM fibre analyser (ANKOM Macedon, NY, USA), according to Van Soest et al. (1991). Digestible energy (DE) was calculated from the equation adapted from McDonald et al. (2010). Digestible energy $(\mathrm{MJ} / \mathrm{kg})=17.47+(0.0076 \times \mathrm{CP} \mathrm{g} / \mathrm{kg})+(0.0158 \times$ acid hy drolysed ether extract $\mathrm{g} / \mathrm{kg})-(0.0331 \times$ ash $\mathrm{g} / \mathrm{kg})$ $-(0.0140 \times \mathrm{NDF} g / \mathrm{kg})$.

\section{Measurements}

Average daily feed intake (ADFI), average daily gain (ADG), feed conversion ratio (FCR), metabolic body weight and final body weight (FBW) were measured. Average daily feed intake (ADFI) for each week was estimated by dividing feed consumed for that week by 7 . Feed consumed was calculated as feed offered minus feed left and spillages. Plastic trays were placed underneath each pen to collect spillages. Average daily gain (ADG) was determined by dividing the difference between body weight at the beginning and the end of each week by 7 . The FCR for each pig was also calculated by dividing ADFI with ADG. Metabolic body weight $\left(\mathrm{BW}^{0.75}\right)$ was
Table 1 Ingredient and chemical composition of diets used

\begin{tabular}{|c|c|c|c|c|c|c|}
\hline \multirow[t]{2}{*}{ Ingredients $(\mathrm{g} / \mathrm{kg})$} & \multicolumn{6}{|c|}{ Decreasing levels of crude protein ( $\mathrm{g} / \mathrm{kg} \mathrm{DM})$} \\
\hline & 193 & 173.7 & 154.4 & 135.1 & 115.8 & 96.5 \\
\hline Yellow maize & 602 & 633 & 688 & 725 & 767 & 720 \\
\hline Soya oil cake & 273 & 208 & 171 & 117 & 750 & 50 \\
\hline Wheat bran & 85 & 119 & 100 & 120 & 120 & 155 \\
\hline Limestone & 13 & 12.5 & 12.1 & 13 & 13.5 & 10 \\
\hline Monocalcium phosphate & 6.0 & 6.0 & 4.0 & 4.0 & 4.0 & 5.0 \\
\hline Oil-sunflower & 5.0 & 5.0 & 5.0 & 0.5 & 5.0 & 5.0 \\
\hline Salt & 5.0 & 5.0 & 5.0 & 5.0 & 5.0 & 5.0 \\
\hline Lysine HCL & 3.8 & 3.8 & 3.8 & 3.8 & 3.8 & 3.0 \\
\hline Threonine & 1.1 & 1.1 & 1.1 & 1.1 & 1.1 & 1.1 \\
\hline Methionine & 1.0 & 1.0 & 1.0 & 1.0 & 1.0 & 0.95 \\
\hline Synth. tryptophan & 0.2 & 0.2 & 0.2 & 0.2 & 0.2 & 0.2 \\
\hline Vitamin-mineral premix & 4.7 & 4.7 & 4.7 & 4.8 & 4.7 & 4.9 \\
\hline \multicolumn{7}{|l|}{ Chemical analysis } \\
\hline Dry matter (g/kg) & 882 & 882 & 876 & 875 & 875 & 876 \\
\hline Calculated DE (MJ/kg DM) & 15.9 & 15.2 & 15.5 & 15.6 & 14.5 & 14.6 \\
\hline Crude protein (g/kg DM) & 202 & 177 & 161 & 145 & 121 & 103 \\
\hline Ether extract (g/kg DM) & 27.2 & 21.7 & 22.0 & 31.2 & 27.2 & 24.1 \\
\hline Neutral detergent fibre (g/kg DM) & 142 & 174 & 158 & 173 & 200 & 197 \\
\hline Acid detergent fibre (g/kg DM) & 44.2 & 50.5 & 47.2 & 47.8 & 45.3 & 46.5 \\
\hline $\operatorname{Ash}(\mathrm{g} / \mathrm{kg} \mathrm{DM})$ & 46.7 & 46.2 & 40.6 & 30.6 & 45.0 & 39.4 \\
\hline \multicolumn{7}{|l|}{ Calculated nutrient analysis } \\
\hline Dry matter (g/kg) & 884 & 883 & 882 & 880 & 879 & 880 \\
\hline Net energy value (MJ/kg DM) & 9.76 & 9.78 & 9.92 & 10.1 & 10.1 & 9.99 \\
\hline Crude protein (g/kg DM) & 192 & 169 & 153 & 137 & 117 & 100 \\
\hline Ether extract (g/kg DM) & 37.2 & 38.0 & 38.2 & 39.0 & 39.4 & 44.1 \\
\hline Crude fibre (g/kg DM) & 27.3 & 28.6 & 25.9 & 26.4 & 25.3 & 27.3 \\
\hline Ash (g/kg DM) & 54.8 & 52.8 & 50.3 & 46.5 & 45.0 & 55.2 \\
\hline
\end{tabular}


calculated as weight ${ }^{0.75}$. Weighing of pigs was done every week from $0700 \mathrm{~h}$ to $0830 \mathrm{~h}$ throughout the trial.

\section{Statistical analyses}

For the repeated measurements, such as ADFI, ADG, FCR and $\mathrm{BW}^{0.75}$ during growth, the SAS PROC MIXED (SAS, 2008) was used to test for significance of the level of crude protein and week on performance parameters. The first-order autoregressive correlation (AR [1]) was fitted to the model. The initial body weight of pigs was included in the model as a covariate. The regression model PROC REG (SAS, 2008) was used to determine the relationships between protein inclusion levels against $\mathrm{ADFI}, \mathrm{ADG}, \mathrm{FCR}, \mathrm{BW}^{0.75}$ and FBW. Then, the $\mathrm{CP}$ criterion was used to determine a model maximizing protein level with as few variables as possible. The piecewise regression (broken stick) analysis using the PROC NLIN (SAS, 2008) procedure was used to determine the optimum inclusion levels of dietary protein on FCR, FBW and $\mathrm{BW}^{0.75}$. A level of $p<0.05$ was set at the criterion for statistical significance. The piecewise regression model used was

$Y_{\mathrm{i}}=y_{\mathrm{o}}+y_{1}+y_{2}\left(I x_{\mathrm{c}}\right)\left(x_{\mathrm{i}}-x_{\mathrm{c}}\right)+\varepsilon_{\mathrm{i}}$

Using parameters $\left(y_{\mathrm{o}}, y_{1}, y_{2}\right)$ and the $x_{\mathrm{c}}$, the two segmented simple regression functions were

$Y_{\mathrm{j}}=y_{\mathrm{o}}+y_{1}\left(x_{\mathrm{i}}\right)$, for $x_{\mathrm{i}} \leq x_{\mathrm{c}} ;$ and

$Y_{\mathrm{k}}=y_{\mathrm{o}}+\left(y_{1}+\mathrm{y}_{2}\right) x_{\mathrm{i}}$, for $x_{\mathrm{i}} \geq x_{\mathrm{c}}$

where $Y_{\mathrm{i}}$ is the response variable when crude protein inclusion level is constraining performance; $Y_{\mathrm{j}}$ is the response variable before the level of crude protein diet compromise performance; and $Y_{\mathrm{k}}$ is the response variable when the level of crude protein in the diet exceeds the optimal level;

Yo $=$ yo-y2 xc;

when $x_{\mathrm{i}}=0$;

$y_{\mathrm{o}}$ is the intercept or minimum $Y_{\mathrm{i}}$ when $x_{\mathrm{c}}<0 ; y_{1}$ is the rate of change of $Y_{\mathrm{i}}$ when $x_{\mathrm{i}}<x_{\mathrm{c}} ; y_{2}$ is the rate of increase in $Y_{\mathrm{i}}$ when $x_{\mathrm{i}}>x_{\mathrm{c}} ; x_{\mathrm{i}}$ is the level of crude protein in the diet; $x_{\mathrm{c}}$ is the optimal protein level beyond which performance is compromised by a decrease in the level of crude protein in the diets; and $I x_{\mathrm{c}}$ is a dummy variable with value 0 when $x_{\mathrm{i}}$ $<x_{\mathrm{c}}$ and 1 when $x_{\mathrm{i}} \geq x_{\mathrm{c}}$. Measurements done were considered significant at $p<0.05$.

\section{Results}

The significance levels of the effect of a diet with decreasing levels of dietary protein on growth performance in Windsnyer pigs are illustrated in Table 2. Dietary proein level affected body weight $(\mathrm{BW})$, metabolic body weight $\left(\mathrm{BW}^{0.75}\right)$, and average daily feed intake (ADFI) affected average daily gain $(\mathrm{ADG})$ and feef conversion ration (FCR) $(p<0.01)$. The dietary protein level affected all measured parameters and their response that were different during the 8-week study period $(p<0.01)$. The dietary protein level and the week of feeding had a significant interaction on AFDI, ADG and FCR ( $p$ $<0.01)$ but did not affect $\mathrm{BW}$ and $\mathrm{BW}^{0.75}(p>0.05)$.

The relationship between varying levels of $\mathrm{CP}$ and performance parameters is shown in Table 3. The relationship between dietary protein levels and ADFI was not significant $(p>0.05)$. Dietary protein levels were not related to ADG $(p>0.05)$. Feed conversion ratio exhibited a decreasing quadratic response against decremental levels of CP $(p<0.01)$. As levels of protein decreased, FCR decreased until reaching $135.1 \mathrm{~g} / \mathrm{kg}$ and after that, it started to increase. There was an increasing quadratic relationship between dietary protein levels against FBW and $\mathrm{BW}^{0.75}(p<0.01)$. As levels of protein decreased, FBW and $\mathrm{BW}^{0.75}$ increased until reaching $135.1 \mathrm{~g} / \mathrm{kg}$ and thereafter, it started to decrease.

The relationship between the week of feeding against ADFI, ADG, FCR and $\mathrm{BW}^{0.75}$ is shown in Table 4. There was a quadratic relationship between weeks of feeding and ADFI in pigs fed diet containing reduced protein level ( $p$ $<0.05)$. As the week progressed, ADFI increases until the 6th to the 7th week, and then it decreased. The quadratic response between ADG and weeks of feeding reduced dietary protein level was observed $(p<0.05)$. As the week progressed, ADG increased until the 5th week, and then it decreased afterwards. There was a decreasing quadratic relationship between weeks of feeding and FCR $(p<0.05)$. A positive linear relationship between
Table 2 Significance levels ( $p$ value) for the effect of dietary protein level, week and their interaction on growth performance in slow-growing pigs

\begin{tabular}{lccc}
\hline Parameter & Protein level & Week & Protein level $\times$ Week \\
\hline Average daily feed intake & $<.0001$ & $<.0001$ & $<.0001$ \\
Average daily gain & 0.004 & $<.0001$ & $<.0001$ \\
Feed conversion ratio & 0.001 & 0.003 & $<.0001$ \\
Body weight (BW) & $<.0001$ & $<.0001$ & 0.11 \\
Metabolic body weight $\left(\mathrm{BW}^{0.75}\right)$ & 0.01 & $<.0001$ & 0.22 \\
\hline
\end{tabular}


Table 3 Response of growth performance parameters to reduced dietary protein levels in growing Windsnyer pigs

\begin{tabular}{|c|c|c|c|c|c|c|c|c|c|}
\hline \multirow[t]{2}{*}{ Parameter } & \multicolumn{6}{|c|}{ Dietary protein level as $\mathrm{g} / \mathrm{kg} \mathrm{DM}$ basis } & \multirow[t]{2}{*}{ MSE } & \multicolumn{2}{|l|}{$p$ value } \\
\hline & 193 & 173.7 & 154.4 & 135.1 & 115.8 & 96.5 & & Linear & Quadratic \\
\hline ADFI (kg/day) & $1.24 \pm 0.036$ & $1.34 \pm 0.035$ & $1.22 \pm 0.033$ & $1.12 \pm 0.034$ & $1.43 \pm 0.035$ & $1.13 \pm 0.033$ & 0.034 & 0.18 & 0.12 \\
\hline $\mathrm{ADG}(\mathrm{kg} /$ day $)$ & $0.29 \pm 0.017$ & $0.34 \pm 0.018$ & $0.27 \pm 0.018$ & $0.27 \pm 0.018$ & $0.35 \pm 0.019$ & $0.24 \pm 0.018$ & 0.018 & 0.09 & 0.16 \\
\hline FCR & $3.18 \pm 0.322$ & $3.06 \pm 0.325$ & $2.63 \pm 0.326$ & $2.13 \pm 0.326$ & $3.43 \pm 0.328$ & $4.77 \pm 0.325$ & 0.325 & 0.25 & 0.004 \\
\hline FBW (kg) & $39.5 \pm 1.286$ & $40.6 \pm 1.284$ & $43.5 \pm 1.285$ & $45.1 \pm 1.284$ & $35.4 \pm 1.285$ & $34.7 \pm 1.285$ & 1.285 & 0.008 & 0.001 \\
\hline $\mathrm{BW}^{0.75}(\mathrm{~kg})$ & $12.8 \pm 0.635$ & $12.9 \pm 0.636$ & $14.1 \pm 0.637$ & $14.6 \pm 0.636$ & $11.8 \pm 0.636$ & $11.4 \pm 0.636$ & 0.636 & 0.002 & 0.001 \\
\hline
\end{tabular}

$M S E$, standard error of the mean; $F B W$, body weight; $B W^{0.75}$, metabolic weight; $A D F I$, average daily feed intake; $A D G$, average daily gain; $F C R$, feed conversion ratio

progressive weeks of feeding experimental diet and $\mathrm{BW}^{0.75}$ was observed $(p<0.05)$.

Optimum levels of protein in the diet without compromising growth performance were estimated using the broken stick analysis (Table 5). The optimum protein level for FCR was estimated at $138.3 \mathrm{~g} / \mathrm{kg}$ protein level and the plateau was estimated at $2.70(p<0.05)$. For $\mathrm{BW}^{0.75}$ and FBW, the threshold of protein levels was estimated at 132.1 and $132.3 \mathrm{~g} / \mathrm{kg}$, respectively. The plateau of $\mathrm{BW}^{0.75}$ and FBW was estimated at $31.6 \mathrm{~kg}$ and $13.3 \mathrm{~kg}(p<0.05)$, respectively.

\section{Discussion}

No health problems occurred throughout the experimental period and no feed refusal was experienced. Decreasing protein levels were formulated by increasing fibre source such as white bran at the expense of soybean meal to reach the desired low levels of dietary protein. Windsnyer pigs have the ability to effectively utilize high fibre by virtue of specialized microbial community in the colon (Kanengoni et al., 2014; Ncobela et al., 2018).

The absence of a relationship between ADFI and protein levels is similar to the findings obtained by Noblet et al. (2001) who reported no effect of dietary protein levels on feed intake of growing pigs. Likewise, Gloaguen et al. (2014) and Toledo et al. (2014) observed no influence of reduced dietary protein on feed intake. No effect of protein levels to feed intake may suggest that nutrient density across diet was similar. The non-significant relationship between decremental levels of protein and ADG concurs with findings reported by Fuller et al. (1995) and Campbell and King (1982). This suggests that digestion and absorption of diets containing decreasing levels of protein were not different across protein levels. This also explains the lack of relationship between decreasing levels of protein and ADFI. This clearly highlights the need to redefine protein requirements for slow-growing indigenous pigs. Carter et al. (2016) reported that the nutrient requirements of local pigs are lower than those of exotic breeds. An increase in ADFI and ADG as the week proceeded could be associated with an increase in body size from about $24.4 \mathrm{~kg}$ in week 1 to $39.8 \mathrm{~kg}$ in week 8 . As pigs grow, it is expected that feed intake would increase in view of increasing gut capacity.

A quadratic decrease in FCR as the dietary protein level decreased in the diet is in line with the findings of Barea et al. (2007) and Toledo et al. (2014). Similarly, Fang et al. (2019) reported that reducing dietary protein from 237 to $169 \mathrm{~g} / \mathrm{kg}$ led response on the gain to feed ratio. The Windsnyer growing pig's response to reduced dietary protein from 193 to $135.1 \mathrm{~g} / \mathrm{kg}$ improved FCR (from 3.18 to 2.13 ) by $33 \%$, but further reductions are not because FCR is compromised. The quadratic response in FCR to reduced dietary protein levels from 200 to $156 \mathrm{~g} / \mathrm{kg}$ (Chrystal et al., 2020) and 197.5 to $162.5 \mathrm{~g} / \mathrm{kg}$ (Greenhalgh et al., 2020) was reported in broiler. The negative effect of decremental levels of protein beyond the threshold to FCR could be associated with increased fat deposition. Literature indicates that monogastric animals offered low-protein diets have a high intake of energy than protein and the excess energy is deposited as lipid (Noblet et al., 2001; Chrystal et al., 2020; Greenhalgh et al., 2020). Low-protein diets in the present study were achieved through partial replacement of soybean meal with maize and wheat bran. This approach has been heavily linked to starch to protein disappearance rate ratio, which in turn affects the starchprotein digestive process (Chrystal et al., 2020; Greenhalgh et al., 2020). The response of Windsnyer pigs suggests that a rise in the amount of starch digested in proportion to that of protein compromises FCR.

A decrease in FCR as protein levels decrease emphasizes that protein needs for Windsnyer pigs are relatively lower than those of NRC (2012). An increase in FCR as protein levels further decrease beyond $135.1 \mathrm{~g} / \mathrm{kg}$ suggests protein requirements must be kept around $135 \mathrm{~g} / \mathrm{kg}$. Further decrease in the protein level beyond $135.1 \mathrm{~g} / \mathrm{kg}$ restricted muscle growth, resulting in the high amount of feed needed to increase a body mass by $1 \mathrm{~kg}$. The level of dietary protein required for slow-growing Windsnyer pigs was lower than recommended by NRC (2012) for growing pigs in the body weight range of $25-50 \mathrm{~kg}$. 


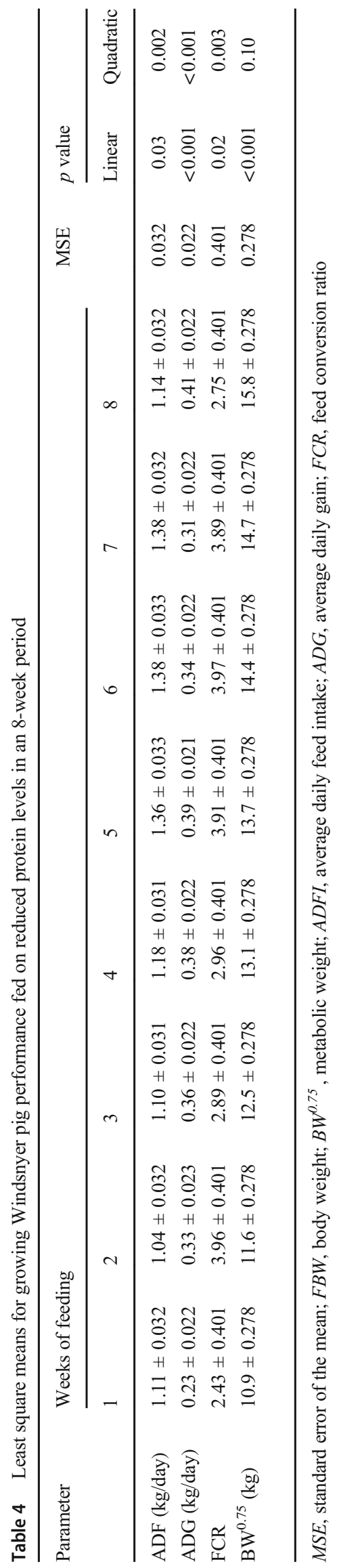


Table 5 Optimal levels beyond which performance parameters in growing Windsnyer pigs is compromised by low levels of dietary protein

\begin{tabular}{|c|c|c|c|c|c|c|c|c|c|}
\hline \multicolumn{3}{|l|}{$Y_{0}$} & \multicolumn{2}{|l|}{$Y_{1}$} & \multicolumn{2}{|l|}{$Y_{2}$} & \multirow[t]{2}{*}{$X_{\mathrm{c}}$} & \multirow[t]{2}{*}{ Plateau } & \multirow[t]{2}{*}{$p$ value } \\
\hline Parameter & Estimate & $\pm \mathrm{SE}$ & Estimate & $\pm \mathrm{SE}$ & Estimate & $\pm \mathrm{SE}$ & & & \\
\hline Feed conversion ratio & 11.9 & \pm 0.20 & -1.36 & \pm 1.88 & 0.053 & \pm 0.126 & 138.3 & 2.7 & $<0.001$ \\
\hline Final body weight $(\mathrm{kg})$ & 31.6 & \pm 1.08 & -0.0087 & \pm 0.52 & -0.051 & \pm 0.052 & 132.1 & 31.6 & 0.001 \\
\hline Metabolic weight ${ }^{0.75}$ & 13.3 & \pm 0.34 & -0.00044 & \pm 0.17 & -0.016 & \pm 0.017 & 132.3 & 13.3 & 0.003 \\
\hline
\end{tabular}

$S E$, standard error; $y_{\mathrm{o}}$ is the intercept or minimum $Y_{\mathrm{i}}$ when $x_{\mathrm{c}}<0 ; y_{1}$ is the rate of change of $Y_{\mathrm{i}}$ when $x_{\mathrm{i}}<x_{\mathrm{c}} ; y_{2}$ is the rate of increase in $Y_{\mathrm{i}}$ when $x_{\mathrm{i}}>x_{\mathrm{c}} ; x_{\mathrm{i}}$ is the level of crude protein in the diet; $x_{\mathrm{c}}$ is the optimal level beyond which performance is compromised by decrease in the level of crude protein in the diets

Reducing dietary protein level from 193 to $135.1 \mathrm{~g} / \mathrm{kg}$ improved the body weight (from 39.5 to $45.1 \mathrm{~kg}$ ) and metabolic body weight (from 12.9 to 14.6 ) by $14.2 \%$, and further reduction led to compromised body weight $(34.7 \mathrm{~kg})$ and metabolic body weight (11.4). A quadratic increase in FBW and $\mathrm{BW}^{0.75}$ as dietary protein level decreased could be associated with crude protein to energy ratio and non-essential amino acids in the diet. The reported results are concordant with findings by Liu et al. (2015) who found that low dietary protein/energy ratio did not affect the growth performance of Bama minipigs, a Chinese indigenous mini-pig breed. An increase in body weight with decreasing levels of protein could be associated with the high availability of dietary energy for fat deposition (Wang et al., 2018). Thus, carcass traits of pork fed decreasing levels of proteins warrant investigation. The growth and development process of pigs such as a change in the body weight depends directly on the breed and diet (Liu et al., 2015). It remains unclear how the dietary nutrients facilitate the effect of genetic difference on growth performance. The poor performance of Windsnyer pigs fed diet containing less than $135.1 \mathrm{~g} / \mathrm{kg}$ could be associated with starch to protein ratio and non-essential amino acids. Further research is needed to understand the reason slow-growing Windsnyer pigs fed apparently required levels of amino acids but with less than $135.1 \mathrm{~g} / \mathrm{kg}$ crude protein compromised performance.

Using the broken stick model, reduction of protein levels in the diet beyond $135.1 \mathrm{~g} / \mathrm{kg}$ constrained FCR. To maximize FCR while meeting protein requirements for growing Windsnyer pigs, these pigs need to be supplied with $70 \%$ of $193 \mathrm{~g} / \mathrm{kg}$ (a protein standard recommendation by the National Research Council 2012). Reduction of dietary protein levels beyond $135.1 \mathrm{~g} / \mathrm{kg}$ compromised $\mathrm{FBW}$ and $\mathrm{BW}^{0.75}$ indigenous Windsnyer pigs. To optimize body weight in growing Windsnyer pigs while meeting protein requirements, protein levels need to be around $135.1 \mathrm{~g} / \mathrm{kg}$. Hlatini et al. (2020) reported that reducing dietary protein level from 193 to $135.1 \mathrm{~g} / \mathrm{kg}$ led to improved nitrogen excretion, nitrogen utilization and biological value of feed protein in growing Windsnyer pigs. Reduction in dietary protein levels in the diets of indigenous Windsnyer pigs is necessary from an economic and environmental point of view. To consolidate investigation on protein requirements for growing Windsnyer pigs, there is a need for further research on digestibility, blood metabolites and carcass and pork quality. The availability of Windsnyer pigs for the experiment limited the study from estimating equation for protein to predict performance. Therefore, instead of more, only five pigs in each experimental diets were used.

\section{Conclusions}

Feed conversion ratio decreased with decreasing levels of protein. Body weight increased with decreasing levels of protein. Growing Windsnyer pigs require protein levels of $135.1 \mathrm{~g} / \mathrm{kg}$ in the diets for maximum FCR, $\mathrm{BW}^{0.75}$ and FBW. Gradual reduction of dietary protein level did not compromise the growth performance of growing Windsnyer pigs until protein levels reached $135.1 \mathrm{~g} / \mathrm{kg}$. The present information on protein requirement on Windsnyer indigenous pigs can be useful to pig feed compounders and pig breeders and farmers.

Funding The authors would like to acknowledge the National Research Foundation (grant number; 102702) for funding the project and the University of KwaZulu-Natal competitive grant.

\section{Compliance with ethical standards}

Conflict of interest The authors declare that they have no conflict of interest.

\section{References}

AOAC., 1990. Official Methods of Analysis of the Association of Official Analytical Chemists, 15th edition. Washington DC, USA.

Barea, R., Nieto, R. and Aguilera, J.F., 2007. Effects of the dietary protein content and the feeding level on protein and energy metabolism in Iberian pigs growing from 50 to $100 \mathrm{~kg}$ body weight. Animal, 1 : 357-365.

Campbell, R.G. and King, R.H., 1982. The influence of dietary protein and level of feeding on the growth performance and carcass characteristics of entire and castrated male pigs. Animal Science, 35:177-184.

Carter, N. A., Dewey, C. E., Thomas, L. F., Lukuyu, B., Grace, D and de Lange, C., 2016. Nutrient requirements and low-cost balanced diets, 
based on seasonally available local feedstuffs, for local pigs on smallholder farms in Western Kenya. Tropical Animal Health and Production, 48: 337-347.

Chrystal, P.V., Moss, A.F., Khoddami, A., Naranjo, V.D., Selle, P.H. and Liu, S.Y., 2020. Effects of reduced crude protein levels, dietary electrolyte balance, and energy density on the performance of broiler chickens offered maize-based diets with evaluations of starch, protein, and amino acid metabolism. Poultry Science, 99:1421-1431.

Fang, L.H., Jin, Y.H., Do, S.H., Hong, J.S., Kim, B.O., Han, T.H. and Kim, Y.Y., 2019. Effects of dietary energy and crude protein levels on growth performance, blood profiles, and nutrient digestibility in weaning pigs. Asian-Australasian journal of animal sciences, 32: p.556.

Fuller, M.F., Franklin, M.F., McWilliam, R. and Pennie, K., 1995. The responses of growing pigs, of different sex and genotype, to dietary energy and protein. Animal Science, 60: 291-298.

Gallo, L., Dalla Montà, G., Carraro, L., Cecchinato, A., Carnier, P. and Schiavon, S., 2014. Growth performance of heavy pigs fed restrictively diets with decreasing crude protein and indispensable amino acids content. Livestock Science, 161: 130-138.

Gloaguen, M., Le Floc'h, N., Corrent, E., Primot, Y. and Van Milgen, J., 2014. The use of free amino acids allows formulating very low crude protein diets for piglets. Journal of Animal Science, 92: 637-644.

Greenhalgh, S., McInerney, B.V., McQuade, L.R., Chrystal, P.V., Khoddami, A., Zhuang, M.A., Liu, S.Y. and Selle, P.H., 2020. Capping dietary starch: Protein ratios in moderately reduced crude protein, wheat-based diets showed promise but further reductions generated inferior growth performance in broiler chickens from 7 to 35 days post-hatch. Animal Nutrition 6:168-178

Hansen, M.J., Nørgaard, J.V., Adamsen, A.P.S. and Poulsen, H.D., 2014. Effect of reduced crude protein on ammonia, methane, and chemical odorants emitted from pig houses. Livestock Science, 169: 118-124.

He, L., Wu, L., Xu, Z., Li, T., Yao, K., Cui, Z., Yin, Y. and Wu, G., 2016. Low-protein diets affect ileal amino acid digestibility and gene expression of digestive enzymes in growing and finishing pigs. Amino Acids, 48: 21-30.

Heo, J. M., Kim, J. C., Hansen, C. F., Mullan, B. P., Hampson, D. J and Pluske, J. R., 2008. Effects of feeding low protein diets to piglets on plasma urea nitrogen, faecal ammonia nitrogen, the incidence of diarrhoea and performance after weaning. Archives of Animal Nutrition, 62, 343-358.

Hlatini V. A, Ncobela, C.N. and M Chimonyo, 2020. Nitrogen balance response to varying levels of dietary protein in slow-growing Windsnyer pigs. South African Journal of Animal Science, 50: 643-653.

Huang, Y., Zhou, L., Zhang, J., Liu, X., Zhang, Y., Cai, L., Zhang, W., Cui, L., Yang, J., Ji, J. and Xiao, S., 2020. A large-scale comparison of meat quality and intramuscular fatty acid composition among three Chinese indigenous pig breeds. Meat Science, 168 p.108182.

Kanengoni, A.T., Chimonyo, M., Erlwanger, K.H., Ndimba, B.K. and Dzama, K., 2014. Growth performance, blood metabolic responses, and carcass characteristics of grower and finisher South African Windsnyer-type indigenous and Large White $\times$ Landrace crossbred pigs fed diets containing ensiled corn cobs. Journal of Animal Science, 92: 5739-5748.

Kasprzyk, A. and Bogucka, J., 2020. Meat quality of Pulawska breed pigs and image of longissimus lumborum muscle microstructure compared to commercial DanBred and Naima hybrids. Archives Animal Breeding, 63: 293-301.

Liu, Y., Kong, X., Jiang, G., Deng, J., Yang, X., Li, F and Yin, Y., (2015). Effects of dietary protein/energy ratio on growth performance, carcass trait, meat quality, and plasma metabolites in pigs of different genotypes. Journal of Animal Science and Biotechnology, 6:36.

Ly, N. T. H., Loc, N. T., Hang, D. T. and Thuan, T. T., 2003. Effect of dietary protein level on the performance of growing pigs under village conditions in Central Vietnam. In: Proceeding of the final national seminar-workshop on sustainable livestock production on local feed resources, Preston, R. and B. Ogle (Eds.). HUAFSAREC, Hue City.

McDonald, P., Edwards, R.A., Greenhalgh, J.F.D., Morgan, C.A., Sinclair, L.A., Wilkinson, R.G., 2010. Animal Nutrition 7th ed. pp 479-607 (Pearson: London).

Mpendulo, C. T., Hlatini, V. A., Ncobela, C. N and Chimonyo, M., 2018. Effect of fibrous diets on chemical composition and odours from pig slurry. Asian-Australasian Journal of Animal Sciences, 31: p.1833

Ncobela, C.N., Kanengoni, A.T., Thomas, R.S. and Chimonyo, M., 2018. Voluntary feed intake and growth performance of slow-growing pigs fed increasing levels of ensiled potato hash meal. Tropical Animal Health and Production, 50: 113-120.

Nistor, E., Bampidis, V., Pentea, M., Prundeanu, H., and Ciolac, V., 2012. Nutritional quality of pork produced by Mangalitsa breed. Journal of Animal Science and Biotechnology., 45: 386-389.

Noblet, J., Le Bellego, L., Van Milgen, J. and Dubois, S., 2001. Effects of reduced dietary protein level and fat addition on heat production and nitrogen and energy balance in growing pigs. Animal Research, 50: 227-238.

NRC, 2012. Nutrient Requirements of Swine, 11th rev. Natl Acad. Press. Washigton.

Pham, K. T., Hoang, N. D., Duc, N. L., Hendricks, W. H., van de PeetSchwering, C. M. C. and Verstegen, M. W. A., 2010. Effects of genotype and dietary protein level on the growth performance and carcass characteristics of fattening pigs in Central Vietnam. AsianAustralian Journal of Animal Science, 23: 1034-1042.

Phengsavanh, P. and Lindberg, J.E., 2013. Effects of Dietary Protein Levels on Growth Performance and Feed Intake in Native Moo Lath Lao Pigs. Journal of Animal and Veterinary Advances, 12: 406-411.

SAS, (2008). SAS User's Guide: Statistics, Version9.1. SASInstitute, Cary.

Sirtori, F., Acciaioli, A., Pugliese, C., Bozzi, R., Campodoni, G. and Franci, O., 2010. Effect of dietary protein level (as substitution of maize with soybean meal) on growth rate and feed efficiency of the Cinta Senese pig in the growing-fattening period. Italian Journal of Animal Science, 910. p.e30.

Toledo, J.B., Furlan, A.C., Pozza, P.C., Carraro, J., Moresco, G., Ferreira, S.L. and Gallego, A.G., 2014. Reduction of the crude protein content of diets supplemented with essential amino acids for piglets weighing 15 to 30 kilograms. Revista Brasileira de Zootecnia, 43: 301-309.

Van Soest, P.J., Robertson, J.B., Lewis, B.A., 1991. Methods for dietary fiber, neutral detergent fiber, and nonstarch polysaccharides in relation to animal nutrition. Journal of Dairy Science 74: 3583-3597

Wang, Y., Zhou, J., Wang, G., Cai, S., Zeng, X and Qiao, S., 2018. Advances in low-protein diets for swine. Journal of Animal Science and Biotechnology, 9, p.60.

Whittemore, C.T., Green, D.M. and Knap, P.W., 2001. Technical review of the energy and protein requirements of growing pigs: protein. Animal Science, 73: 363-373.

Publisher's note Springer Nature remains neutral with regard to jurisdictional claims in published maps and institutional affiliations. 